\title{
ROLE CONTRADICATIONS BETWEEN CONSULTANTS OF ACCOUNTANT SERVICES AND PUBLIC ACCOUNTANT OFFICES
}

\author{
Fitriana Santi ${ }^{1)}$, Ary Yunita Anggraeni ${ }^{2)}$ \\ ${ }^{1)}$ Fakultas Ekonomi dan Bisnis, Universitas Merdeka Malang \\ fitriana.santi@unmer.ac.id \\ ${ }^{2)}$ Fakultas Ekonomi dan Bisnis, Universitas Merdeka Malang \\ ary.yunita@unmer.ac.id
}

\begin{abstract}
The Office of Accountant Services is an accounting services office that is allowed to provide management services, taxation and assurance service. The thing that distinguishesbetween KJA and KAP is where the Public Accountant Office is allowed to provide assurance and audit services. In practice there was a dualism of work where the services provided by KJA could also be provided by KAP. While the services provided by KAP cannot be provided by KJA. This is what results in the intersection of interests between KAP and KJA. The reason for the struggle for market share is also their basis for fighting over clients. If thiscontinues, they are not impossible to not focus on the quality of services provided. The writing of this article explains the intersection between these two accounting service offices. Where there is a mental accounting theory that is the background of the dispute between these two service offices.
\end{abstract}

Keyword: KJA, KAP and Mental

\section{INTRODUCTION}

The increasingly rapid economic development each day is also offset by the development of competitors between countries. The development of globalization is inseparable from the impact, including the impact on the role of public accountants and the Office of Accountant Services (KJA). The increasing number of companies each year has resulted in the increasing demand for adequate financial statement presentation. The role of KJA, which is currently busy and warmly discussed, has been able to provide fresh air for the owners of the company.

Companies that have been running for a long time are in fact many of them do not have a company accountant. As a result, they forget the importance of making financial statements. Not only that, even the phenomenon in the field is often found, that companies that have large turnover have not or even do not have financial reports. Even if it is viewed from its function, financial 
statements are a tool used as a company controller. Financial statements are also important as a basis for decision making, as well as a reflection of the company's past performance and references for planning future performance.

The company's owner's awareness of the importance of financial statements is the opportunity for KJA. In contrast to the Public Accountant Office that is familiar to us, agreed procedure services for financial information and information technology system services. The Accounting Services Office is an accounting service outside of insurance services. This means that KJA is only allowed to provide management services, financial reporting services, tax services, and management consulting services. The existence of the Accountant Service Office is under the umbrella of the Minister of Finance Regulation Number 216 / PMK.01 / 2017. In accordance with the regulations given, only the accountant who has a certificate gets permission from the finance minister to establish accounting services. This Accounting Services Office can be a form of business in the form of individuals, firms and limited liability companies.

The presence of KJA is widely used by business people to support the credibility of their financial statements. Business people now rely more on their financial statements on KJA because KJA has a good and bankable perception, given that business activities are never separated from working capital originating from debt. Not only are these two benefits felt by business people, because KJA is handled by professional accountants thus company owners are more flexible in conducting business. This happens because the company's financial statements are done neatly and accountable by KJA. Then this neat financial report can be used as a company controller in policy making. The neatness and clarity of the financial statements produced by the KJA are also acceptable thus they can be used as supporters of expansion and cooperation with investors both from within and outside the country.

Not only is this above the presence of KJA which plays a professional role and certainly apart from a conflict of interest makes the company avoid fraud and internal policies. The advantages of the use of KJA services are also felt by 
the level of the board of directors, namely they will be able to focus more on strategic planning, because financial statements have been handled by KJA systematically and certainly meet compliance with company policies and financial standards. In addition to providing financial reporting services, in line with the explanation above, KJA also provides management consulting services for business people who want to develop their business activities. In addition, KJA also provides tax services that are currently very much needed by companies both from large and small levels. Relationships that cannot be separated between financial statements and companies are what make business companies use KJA as the solution.

If the making of financial statements can be resolved the next problem is the users of financial statements. One user of the company's financial statements is the auditor or commonly referred to as a public accountant. Some public accountants are internal and some are external. Both internal and external the presence of public accountants must be independent. Public accountants have a house or special container called the Public Accountant Office (KAP). One of the services provided by KAP is assurance services. The company's financial statements are now an obligation to be examined in order to be able to produce reasonableness and be useful for stakeholders. Therefore, audit activities must be carried out by professional and independent public accountants.

When referring to PMK No. 154 / PMK.01 / 2017 KAP it is permissable to provide insurance services and non-insurance services. Insurance services are audit services, while non-insurance services consist of accounting services, financial technology systems and management consulting services. Not only making financial statements carried out by KAP, tax services are also provided by KAP. When looking at the services provided, there is a dualism of work in one profession. Both KAP and KJA are a container that holds a public accountant. However, GAP often found in the field between KJA and KAP. This happens because there is a point where one work is offered to business people. There is often a debate over why KJA is not allowed to use insurance 
services carried out by KAP. Why KJA is often feared by not being allowed to give opinions on financial statements. Even though in reality in the field business people often come to KJA to solve all problems faced, both the problem of making financial statements and the fairness of the financial statements.

The role of KJA is not only limited to preparing financial statements, but KJA also has responsibility for the "face" of the financial statements that it has prepared. This face determines the sustainability of the company in the future. Logically, KJA is also obliged to respond to reports that have been made, because KJA knows the details and history of its preparation. By not reducing the role of KAP, KJA is more appropriately referred to as the vanguard to oversee and filter financial statements to comply with applicable regulations. Of course this is not easy to do considering the wider role of KAP when compared to KJA.

\section{LITERATURE REVIEW}

\section{Accountant Services Office}

The Minister of Finance has ratified the Minister of Finance Regulation (PMK) Number 25 / PMK.01 / 2014 concerning State Registered Accountants. This PMK will become a new foundation for the accounting profession in building professional quality that is more reliable and capable to compete in the global arena. These PMKs, among others, regulate the mechanism of reregistration, fostering professional accountants, professional accounting education and professional accounting certification examinations, and the mechanism for establishing accounting services offices (KJA).

Unlike the Public Accountant Office (KAP) or Tax Consultant's Office, not many are familiar with the Office of Accountant Services (KJA). This is understandable because the existence of the Accounting Services Office is indeed relatively new. The existence of KJA is covered by the Minister of Finance Regulation Number 216 / PMK.01 / 2017. Based on these regulations, KJA is given a mandate to be able to provide accounting services, management 
services, tax services, and information system services. However, KJA may not provide insurance or audit services as referred to in Article 3 paragraph (1) of Law Number 5 of 2011 concerning Public Accountants. This insurance service is a service provided by a Public Accountant or KAP.

\section{Public Accountant Office}

Accountant (KMK No. 423/KMK.06/2002) is someone who has the right to hold the title or designation of an accountant in accordance with applicable laws and regulations. While the Public Accountant is an accountant who has obtained permission from the Minister to provide services as stipulated in this Decree of the Minister of Finance. According to Arrens (2005) Certified Public Accountants are those who have fulfilled the requirements submitted by the state, including the obligation to take a public accountant exam, and then are entitled to a public accountant certificate; a public accountant has the primary responsibility to carry out the audit function of published historical financial statements, and entities that are financially commercial and non-commercial in nature.

In KMK No. 423/KMK.06/2002 also explained Public Accounting Office or abbreviated as KAP, is a business entity that has obtained permission from the Minister as a place for Public Accountants to provide services. The Office of Public Accountants is an organization created to provide professional accounting services, including audits. Usually established as private ownership or fellowship (Messier, Grover and Prawitt, 2005; 74). The testing of the Public Accountant Office (KAP) is a form of public accountant organization that obtains permits in accordance with the laws and regulations that seek to provide professional services in the practice of public accountants. (Sukrisno, 2004;272).

Services provided by the Public Accountant Office in the form of operational audit services, compliance audits and financial report audits (Halim, 2008: 14). The public expects that the profession of public accounting is a free and impartial assessment of information presented by company 
management in financial statements. Information generated in the form of financial statements can be used as a basis for decision making, the accounting department is required to be able to present information that has relevance, reliability, test power, neutrality, and is presented correctly (Kieso, et al., 2008: 36). The profession of public accountant is very important because the variety of service users make the profession accountable to interested parties. Whether or not the accountability given depends on the auditor's performance, because the work achieved by the auditor in carrying out his duties in accordance with the responsibility given to him.

\section{Mental Accounting}

This theory was originated from Richard Thaler in 1985 as one of the models of consumer behavior developed based on aspects of psychology and microeconomics (Thaler, 1999). This theory states that similar to a company, every human being records and categorizes expenditure into the accounts that are in their minds. In the human mind there is an accounting process such as what is done in a company which includes bookkeeping and evaluation of decision making in consumption. In mental accounting, the components involved include framing effects, specific accounts, self control, decision making, self report, and hedonic treadmill. Humans consider spending as an experience to be evaluated (Thaler, 1999). Business people often assess a company's success from accounting indicators (eg being able to master more resources in the community will result in high profit growth, and expand to beat its competitors).

\section{DISCUSSION}

Ministerial Regulation No, or 25 / PMK 01/2014 speaks of accountants who have been registered. One of the forms of a semesterized accountant is the Accounting Services Office (KJA). In line with the provisions stipulated in article 15 of PMK number 25 / PMK.01 / 2014, KJA is required to submit annual activity reports no later than March. Based on the business activity 
report in 201571 KJA have submitted reports on their business activities. Based on data from the Financial Professional Development Center, it is known that the KJA magnitude is increasingly adding up. This is in line with the increasing KJA income. When viewed from the PPPK chart, it is known that the highest income is KJA in the form of individuals. However, there are still many KJA who have difficulties in obtaining clients.

The problem is not only because many publics do not know about the existence of KJA but also because the competitors of KJA are fellow public accountants, namely the Public Accountants Office. Both offices provide services that are almost the same. This led to competition between the two offices. If this condition is allowed, it is not impossible that there will be a debate between the Accounting Services Office and the Public Accounting Office. It would be better if in the provision of services there is a separator between the

Accounting Services Office and the Public Accounting Office. If KJA is not allowed to provide insurance services and is only allowed to carry out noninsurance services, it is better for all non-insurance services to be provided at KJA. Likewise with KAP, if KAP is given the authority to provide insurance services, then it would be better for KAP to focus on providing insurance services and not non-insurance. Likewise with responsibility. For noninsurance activities carried out by $\mathrm{KJA}$, KJA is fully responsible for the financial statements carried out.

If in practice it turns out that fraud is found, KJA can also be sued for this. Similar to what was done by KAP, if in the provision of audit services KAP has given an opinion error, this should be suspected of fraud. These two offices contribute greatly to the sustainability of the company and have a major impact on the economy. As we know that in practice there are still many KAPs that practice fraud for reasons of fear of not getting clients.

Many of them violate the code of ethics to carry out their activities. Analyzing cases that have happened lately is the case with SNP Finance. The Columbia Group company was in the spotlight of the OJK because the 
company failed to pay MTN interest of Rp.6.75 billion on May 14 2018. In this case it was suspected that there was a deliberate mistake in making financial statements (fictitious financial statements) and the auditor did not give a warning to the fictitious financial statements made. Not only that, the events of manipulating financial statements were also carried out by private banks. Bukopin, for example, on May 3, 2018, it was found that Bukopin bank had manipulated credit card data for 3 years. What is surprising is that these three financial statements can pass various levels, starting from Bukopin's internal auditor, the Public Accountant Office who acts as an independent accountant and Bank Indonesia as the authority system that handles credit cards. The escape of cheating is not impossible due to the beauty of the financial statements that are made, thus it can be ascertained that the accountant making the financial statements also participated in fraudulent activities

Not only happens to cheating companies that are often found in the government sector. Even the bustling of regional head arrest is also not impossible due to the weakness of accountants in the government sector. Often found financial report makers or accountants carry out their duties in accordance with the client's request is not in accordance with generally accepted Accounting Principles. They do this on the grounds that if they do not comply with the client's request, how would they get clients. No longer independent, their attitude more flexible depending on what the client wants. If this action continues, it is precisely from year to year instead of actually decreasing fraud cases, but instead it increases. One of the things that can be done is the existence of good cooperation between KJA and KAP. As explained in the discussion above, it is better to revise the Government Regulation regarding the separation of duties between KJA and KAP. If at this time what we often encounter is in making SPT in filling out tax, the one responsible for KAP and we often encounter it at the beginning of the company's financial statements is the responsibility of an independent audtor. It is better to be slightly amended, where accountability is carried out by two accountants who are registered, namely KJA and KAP. Why KJA? Because 
cheating comes from financial statements. If $\mathrm{KJA}$ is also responsible and includes the name of the financial statement maker both in the SPT and the annual financial report, this might minimize the conduct of fraud. Why does the SPT also need to include the name of the financial report maker? Because it is not impossible for the accountant to manipulate the client's financial statements with the aim of tax deduction or so that in matters of tax the company does not pay too much.

One factor that causes these frauds is the mentality of the individuals involved. The number of loopholes that can be played by KJA and KAP, causes the two parties to strive to obtain an unfair advantage from their profession. The mental accounting theory states that just like companies, every human being records and categorizes expenditures into the accounts that are in their minds. Mental accounting is a cognitive process in which individuals take notes, summarize, analyze, and report transactions or financial events to track the flow of money and control expenses. When they face financial transactions automatically their minds will process whether the sacrifices made will be comparable to those obtained. This will influence the decisions that will be made, of course this decision must be able to provide more benefits for KJA.

This can also be triggered by the imbalance of tasks between KJA and KAP in carrying out their duties. The rights and obligations of each party should be adjusted according to how much responsibility is carried out by both. It is even better if KJA and KAP have good coordination and cooperation, are expected to reduce fraud and make financial statements more comprehensive and transparent.

\section{CONCLUSION}

The Office of Accountant Services and the Public Accounting Office are two accounting services that are currently needed for the business world. From the explanation above, it can be concluded that it would be wonderful if these two offices could work together to provide the services needed for today's business world. If these two offices can work according to their respective job 
descriptions, business people will not be confused. The government should also provide strict rules for the two service offices so that in the future they will not compete with each other for market share. If this happens then it is impossible for their focus to be no longer the quality of accounting services but only "market share". It would be more beautiful if there was a division of tasks carried out by the government, for example giving rules for KJA to focus on the problems that existed in small and medium businesses and if it was large the client could move to the Public Accounting Office.

\section{REFERENCES}

Arens, Alvin A. dan Loebbecke. 2003. “Auditing”. Jakarta : Salemba Empat.

Ikatan Akuntan Indonesia. 2012. Menghadapi AEC 2015, Akuntan Dituntut Menjadi Anggota IAI.1 November 2012 diaksesdari http://www.iaiglobal.or.id/v02/berita/detail.php?catid=\&id=449 pada tanggal 21 November 2014. Ikatan Akuntan Indonesia. (2014).

Halim Abdul. 2008. Auditing (Dasar-Dasar Audit Laporan Keuangan). Yogyakarta:Unit Penerbit dan Percetakkan STIM YKPN.

Menteri Keuangan. 2003. Keputusan Menteri Keuangan Nomor 423/KMK.06/2002 no359/KMK.06/2003 tentang "Jasa Akuntan Publik”. Jakarta.

Menteri Keuangan. 2008. Peraturan Menteri Keuangan Republik Indonesia Nomor 17/PMK.01/2008 pasal 3 tentang "Jasa Akuntan Publik". Jakarta

Messier, W.F., Glover, S.M., dan Prawitt, D.F. 2006. Auditing and Assurance Services a Systematic Approach. Edisi Keempat. Penerbit Salemba 4. McGraw-Hill Irwin.Singapore

Peraturan Menteri Keuangan Republik Indonesia No.25/ PMK.01/2014 Tentang Akuntan Beregistrasi Negara. 17 Febuari 2014 diakses dari www.iaiglobal.or.id/v02/berita/detail.php?catid\&id=623 pada tanggal 24 November 2014. 
Sukrisno Agoes. 2004. Auditing (Pemeriksaan Akuntansi). Fakultas Ekonomui Universitas Indonesia. Jakarta

Thaler, Richard H. 1999. Mental Accounting Matters. Journal of Behavioral Decision Making, vol. 12, pp. 183-206. 